\title{
Correlation Between Matermind-Like Domain Containing 1 (MAMLD1) Gene Mutation with Hypospadias Incidence
}

\author{
Safendra Siregar, Bambang Sasongko Noegroho, Irfan Firmansyah \\ Department of Urology, Faculty of Medicine Universitas Padjadjaran, Dr. Hasan Sadikin Hospital, Bandung, Indonesia \\ Email address: \\ Safendra_sir@yahoo.co.id (S. Siregar) \\ To cite this article: \\ Safendra Siregar, Bambang Sasongko Noegroho, Irfan Firmansyah. Correlation Between Matermind-Like Domain Containing 1 (MAMLD1) \\ Gene Mutation with Hypospadias Incidence. International Journal of Clinical Urology. Vol. 3, No. 1, 2019, pp. 18-21. \\ doi: $10.11648 /$ j.ijcu.20190301.15
}

Received: December 18, 2018; Accepted: August 22, 2019; Published: September 9, 2019

\begin{abstract}
Introduction: Hypospadias is a condition in which the urethral orifice is located on the ventral side of the penis proximal to the tip of the glans, from the balanopreputial sulcus to the perineal area. The gene thought to play a role in the occurrence of hypospadias was the mastermind-like domain gene containing 1 (MAMLD1) or previously known as the CXorf6 gene (chromosome X opens reading frame 6). Aims: This study aims to look at the relationship between the gene mutation of MAMLD1 with hypospadias incidence. Methods: This study is observational analysis with case-control as design studies. The subjects are male patients who diagnose as having hypospadias based on examinations conduct at the Department of Urology Dr. Hasan Sadikin Bandung. The study will be conduct in May 2018 - April 2019. DNA is taken from the skin of penile prepuce in both the case group and the control group. DNA extraction using the Homebrew method at the Eykman Laboratory, Padjadjaran University, Bandung. Mutation analysis will carried out by exon sequencing of MAMLD1 coding using the direct sequencing standard method at the Eykman Genetic Laboratory, Padjadjaran University, Bandung. The data that has been obtained will be analyzed using the chi-square correlation test method, if the chi square requirements are not met, then use the fisher test exact. Results: Average age of patients operated was between 4 - 18 years old and the most frequent type of hypospadias was distal Type. No MAMLD1 polymorphisms were found in experimental group and control groups. Result of MAMLD1 gene sequencing showed there were no mutation in any sample. In other words, from all hypospadias and control patient who were sequenced, the mutation rate was $0 \%$. Conclusion: From this study we concluded that MAMLD1 gene mutation were not different between hypospadias and control groups. We didn't found any MAMLD1 mutation ether in hyposphadia groups or control groups. There was no correlation between MAMLD1 gene mutation with hypospadias incidence.
\end{abstract}

Keywords: Hypospadias, MAMLD1, Mutation

\section{Introduction}

Hypospadias is a condition where the urethral orifice is located on the ventral side of the penis which is proximal from the tip of the glans, from the balanopreputial sulcus to the perineal area. [1-5]. This disorder is classified as mild (glans or penis) or severe (scrotum or perineal) depending on the anatomic location of the meatus urethra. [4] This abnormality results from the late development of urethral fusion. [2] Hypospadias is one of the most common congenital abnormalities in men. [2] This congenital disorder affects 1 in 200 to 300 children in the United States. [2] The prevalence of hypospadias in Indonesia is not well known.
Research conducted by Aritonang et al in Dr. RSUP Cipto Mangunkusumo Jakarta found 124 cases of hypospadias in the period 2002 - 2014. [6]

The cause of hypospadias is still uncertain, especially in mild cases. Several things that are thought to have an influence on the occurrence of hypospadias are environmental and genetic factors. [3] Various studies have found that family hereditary factors influence the occurrence of hypospadias. Family aggregation is believed to be caused more by genetic factors than intrauterine conditions. [5]

The development of the male external genitalia is a complex process and involves various genes and hormonal conditions and their interactions. [2] The process of urethral 
duct formation in the fetus occurs from the 6th week of the first trimester and is androgen-dependent, so abnormalities of androgen metabolism may cause hypospadias. [7, 8]

The occurrence of gene polymorphisms that control androgen and biosynthesis of testosterone and dihydrotestosterone is thought to play an important role in the etiology of hypospadias. [4] However, gene mutations that are related to androgen are found only in a few hypospadias patients. Disrupting chemicals (EDCs) during fetal development can also cause abnormal urethral formation.

Hormone that found to have an important role in the development of the male reproductive system is estrogen. As a steroid hormone, estrogen works through estrogen / estrogen receptor (ER) receptors that are specific and bind to certain parts of DNA and involve coactivators and corespresor which cause changes in the rate of transcription of genes regulated by estrogen. [1] Previous studies have suggested that there is a relationship between estrogen receptors and polimorfism gene in the increase in the occurrence of hypospadias. One of the estimated genes is the mastermind-like domain gene containing 1 (MAMLD1) or previously known as the CXorf6 gene (chromosome X opens reading frame 6). The MAMLD1 gene encodes a protein that acts as a transcription coactivator. Mutations in this gene are related to hypospadias X-linked type 2. [9-11].

The central theme in this study is that hypospadias are congenital abnormalities that arise as a result of several risk factors, one of which is genetic factors. MAMLD1 gene mutation is one of the causes of this congenital abnormality. Therefore, this study are aim to see the relationship between the mutation of gene MAMLD1 with hypospadias in children.

\section{Methods}

This study is observational analysis with case-control as design studies. The subjects of the study are male patients who diagnose with hypospadias based on examinations carried out by a urologist and urology resident in the Urology Department of Dr. RSUP. Hasan Sadikin Bandung, and willing to participate in the research by signing an informed consent after being given an explanation. Patients of boys with growth disorders, congenital abnormalities, born to mothers who had a history of taking drugs during pregnancy will excluded from this study.

The selection of subjects for hypospadias will be carried out in the urology clinic at the RSUP Dr. Hasan Sadikin Bandung, who had previously carried out an assessment. The selection of subjects for control will be carried out in the children's polyclinic of Dr. RSUP Hasan Sadikin Bandung. The study will be conducted in May 2018 - April 2019. DNA extraction, mutation analysis, prediction of in silico structures will be carried out in the Eykman Genetic Laboratory of the University of Padjadjaran, Bandung.

DNA going to taken from the skin of penile prepuce in both the case group and the control group. DNA extraction using the Homebrew method at the Eykman Laboratory, Padjadjaran University, Bandung. Mutation analysis will be carried out by exon sequencing of MAMLD1 coding using the direct sequencing standard method at the Eykman Genetic Laboratory, Padjadjaran University, Bandung. as shown in table 1.

Table 1. Primes use for amplification of exon 3 part 1-3.

\begin{tabular}{lll}
\hline & Forward & reverse \\
\hline Exon 3 part 1 & CTCTCTTCTCCTCTTCTCTTCTCT & GGTGAGCTCCTCTAGCAGCTCTTG \\
Exon 3 part 2 & GCCGGCTGTAGACCAGGAGC & GGGCGTGATGCCACTGAGGC \\
Exon 3 part 3 & GTCGCTCTGCCCCCCTTACC & GAATGGAGCTCTGAGGGCCG \\
\hline
\end{tabular}

Furthermore, the data that has been obtained will be analyzed using the chi square correlation test method, if the chi square requirements are not met, then use the fisher test exact.

\section{Results}

Average age of patients operated was between $4-18$ years old and the most frequent type of hypospadias was distal type as shown in tables 2 and 3 .

Table 2. Characteristic of subjects.

\begin{tabular}{lll}
\hline age & hypospadias & control \\
\hline $4-9$ & 15 & 13 \\
$10-14$ & 8 & 11 \\
$>15$ & 7 & 6 \\
Total & 30 & 30 \\
\hline
\end{tabular}

Table 3. Characteristics of hypospadias type.

\begin{tabular}{ll}
\hline Type of hypospadias & Number \\
\hline Distal & $18(60 \%)$ \\
Proximal & $12(40 \%)$ \\
Total & $30(100 \%)$ \\
\hline
\end{tabular}

No MAMLD1 polymorphisms were found in experimental group and control groups. Result of MAMLD1 gene sequencing showed there were no mutation in any sample. In other words, from all hypospadias and control patient who were sequenced, the mutation rate was $0 \%$.

\section{Discussion}

The results of this study showed that the most common age group of hypospadias patients is in the age group of 4-18 years old which included 30 patients. The most common age groups in the study were 5 years old. In this study, the most common type of hypospadias was the distal type as many as 
18 patients $(60 \%)$, while the proximal type was only 12 patients $(40 \%)$.

The etiology of hypospadias is thus regarded as complex, with both genetic and environmental contributions. Environmental factors not only on the endocrine disruptor, but also on individual sensitivity modulated by genetic background, including gene polymorphisms. [18]

Previous studies have reported that the polymorphisms of genes implicated in penile development and/or urethral formation are associated with hypospadias by modulating the cellular and molecular actions of androgens and estrogens. Increases in GGN trinucleotide repeats in the gene encoding the androgen receptor (AR) and the less active variant of SRD5A2 (5a-reductase gene), the V89L polymorphism are both reported to increase the risk of hypospadias. On the other hand, polymorphisms of ERb1, ERb2 and ESR1 may increase susceptibility to xenoestrogens and increase the risk of the malformation (10\%). Activating transcription factor 3 (ATF3), an estrogen-dependent CREB family transcription factor in human, exhibits polymorphisms in patients with hypospadias. [19]

The mechanism by which a MAMLD1 polymorphism would modulate the risk of hypospadias may implicate testosterone production during the critical period of sex differentiation. Indeed, transient knockdown of Mamld1 with small interfering RNAda molecular method to block the action of a protein in vitro showed reduced testosterone production in a mouse model of Leydig cells. Steroidogenic factor 1 (SF-1) proteinda protein that interacts with the enzymes of steroidogenesis and testosterone productiondis able to bind a specific sequence in the upstream of the Mamld1 coding region and exert transactivation activity. Last, in situ hybridization analysis for the murine homologous gene showed a cell-specific expression pattern in Sertoli and Leydig cells. Surprisingly, the polymorphisms we identified were present in hypospadiac patients with normal plasmatic testosterone. This is similar to previously described mutations of MAMLD1. The timing of MAMLD1 expression could explain this apparent discrepancy. Fukami et al. showed that the gonadal expression of MAMLD1 homologue in mouse was present only from E12.5 to E14.5, which is the critical period of sex differentiation. In the postnatal testis, weak expression of MAMLD1 was identified in the cords until one week of age and became faint thereafter. MAMLD1 dysfunction may induce a transient testicular dysfunction only during this highly sensitive developmental window. Moreover, the fine variation of testosterone during this period may be worsened by prenatal contamination by environmental disruptors and polymorphisms may modulate the individual susceptibility to these factors. [20]

Polymorphisms of MAMLD1 were not found in all hypospadias. In this study we did not explore other factors (like endogen and exogen factors) that could contribute to hypospadias incidence, we only investigated the MAMLD1 gene, but we know there are so much genes that have a correlation to hypospadias and this could be the limitation of the study.

\section{Conclusion}

From this study we concluded that MAMLD1 gene mutation were not different between hypospadias and control groups. There was no correlation between MAMLD1 gene mutation with hypospadias incidence. in other words, from all hypospadias and control patient who were sequenced, the mutation rate was $0 \%$. The limitation of this study are in this study we did not have much samples and we did not explore other factors (like endogen and exogen factor) that could contribute to hypospadias incidence, we only investigated the MAMLD1 gen, but we know there are so much genes that have a correlation to hypospadias.

\section{References}

[1] Beleza-Meireles A, Omrani D, Kockum I, Frisen L, Lagerstedt K, Nordenskjöld A. 2006. Polymorphisms of estrogen receptor $\beta$ gene are associated with hypospadias. Journal of endocrinological investigation; 29 (1): 5-10.

[2] Choudhry S, Baskin LS, Lammer EJ, Witte JS, Dasgupta S, Ma C, et al. 2015. Genetic polymorphisms in ESR1 and ESR2 genes, and risk of hypospadias in a multiethnic study population. The Journal of urology; 193 (5): 1625-31.

[3] Kalfa N, Cassorla F, Audran F, Abdennabi IO, Philibert P, Beroud C, et al. 2011. Polymorphisms of MAMLD1 gene in hypospadias. Journal of pediatric urology; 7 (6): 585-91.

[4] Samtani R, Bajpai M, Vashisht K, Ghosh P, Saraswathy K. 2011. Hypospadias risk and polymorphism in SRD5A2 and CYP17 genes: case-control study among Indian children. The Journal of urology; 185 (6): 2334-9.

[5] Sharma N, Bajpai M, Panda S, Singh A, Pandey R, Ali A. Family based genetic study in proximal penile hypospadias with undescended testis.

[6] Krisna DM, Maulana A. 2017. Hipospadia: Bagaimana Karakteristiknya di Indonesia. Berkala Ilmiah Kedokteran Duta Wacana; 02 (02).

[7] Park JM. 2016. Embryology of the Genitourinary Tract. Dalam: Wein AJ, Kavoussi LR, Partin AW, Peters CA (penyunting). "Campbell-Wall Urology". Edisi 11. Bab 122. hlm. 2823-48.e4. Philadelphia: Elsevier, Inc.

[8] Snodgrass WT, Bush NC. 2016. Hypospadias. Dalam: Wein AJ, Kavoussi LR, Partin AW, Peters CA (penyunting). "Campbell-Wall Urology". Edisi 11. Bab 147. hlm. 3399429.e2. Philadelphia: Elsevier, Inc.

[9] Ogata T, Laporte J, Fukami M. 2009. MAMLD1 (CXorf6): a new gene involved in hypospadias. National Center for Biotechnology Information.

[10] Ogata T, Fukami M, Wada Y. 2008. MAMLD1 (CXorf6) is a New Gene for Hypospadias. National Center for Biotechnology Information.

[11] Kalfa N, Cassorla F, Audran F, Abdennabi IO, Philibert P, Béroud C, et al. 2011. Polymorphisms of MAMLD1 gene in hypospadias. National Center for Biotechnology Information. 
[12] Baskin LS, Ebbers MB. 2006. Hypospadias: anatomy, etiology, and technique. Journal of pediatric surgery; 41 (3): 463-72.

[13] Yiee JH, Baskin LS. 2010. Penile embryology and anatomy. The Scientific World Journal; 10: 1174-9.

[14] Tanagho E, McAninch J. 2007. Smith's general urology: McGraw-Hill Prof Med/Tech.

[15] Gearhart JG, Rink RC, Mouriquand PD. 2009. Pediatric urology: Elsevier Health Sciences.

[16] Shih EM, Graham JM. 2014. Review of genetic and environmental factors leading to hypospadias. European journal of medical genetics; 57 (8): 453-63.

[17] van der Zanden LF, van Rooij IA, Feitz WF, Franke B, Knoers NV, Roeleveld N. 2012. Aetiology of hypospadias: a systematic review of genes and environment. Human reproduction update; 18 (3): 260-83.

[18] Fukami M, Wada Y, Miyabayashi K, Nishino I, Hasegawa T, Nordenskjold A, et al. CXorf6 is a causative gene for hypospadias. Nat Genet. 2006; 38: 1369e71.
[19] Fukami M, Wada Y, Okada M, Kato F, Katsumata N, Baba T, et al. Mastermind-like domain containing 1 (MAMLD1 or CXorf6) transactivates the Hes3 promoter, augments testosterone production, and cont.

[20] Kalfa N, Sultan C, Baskin LS. Hypospadias: etiology and current research. Urol Clin North Am. 2010; 37: 159e66.

[21] Baskin LS. 2012. Hypospadias and genital development: Springer Science \& Business Media.

[22] Fernandez MF, Olmos B, Granada A, López-Espinosa MJ, Molina-Molina J-M, Fernandez JM, et al. 2007. Human exposure to endocrine-disrupting chemicals and prenatal risk factors for cryptorchidism and hypospadias: a nested casecontrol study. Environmental health perspectives; 115 (Suppl 1): 8 .

[23] Hadidi A, Montgomery DA. 2013. Hypospadias surgery: an illustrated guide: Springer Science \& Business Media. 